The Israeli Journal of Aquaculture IJA.73.2021.1544378, 13 pages

CCBY-NC-ND-4.0 • https://doi .org/10.46989/001c.29916

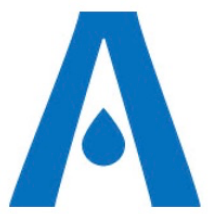

The $I J A$ is a peer-reviewed open-access, electronic journal, freely available without charge to users

Produced by the AquacultureHub non-profit Foundation Sale of IJA papers is strictly forbidden

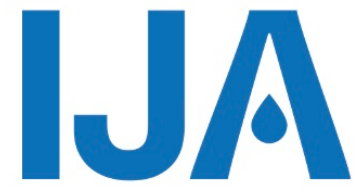

\title{
Analysis of Some Immune Parameters in The Skin Mucus of Four Cultured Fish Species
}

\author{
Esin Baba* \\ Mugla Sitkı Kocman University, Faculty of Fisheries, Department of Aquaculture, Diseases \\ Division 48000, Mugla, Turkey
}

Key words: Keywords: skin mucus, immunity, cultured fish species

\begin{abstract}
The skin mucus layer and its components provide the first line of defense against fish pathogens. The skin mucus samples were taken from four species Nile tilapia (Oreochromis niloticus), rainbow trout (Oncorhynchus mykiss), Siberian sturgeon (Acipenser baerii), and the European sea bass (Dicentrarchus labrax) for analyzing of some immune parameters. It is measured the activities of alkaline phosphatase, lysozyme, myeloperoxidase, bactericidal activity (against Aeromonas hydrophila), total protein and immunoglobulin concentration. The sea bass had highest level of lysozyme, myeloperoxidase, and bactericidal activities, and so were the total protein and immunoglobulin concentrations. The alkaline phosphatase activity in skin mucus measured in Nile tilapia as maximum level while the immune activity observed in sea bass among fish species. The skin mucus determined a more robust bactericidal activity against $A$. hydrophila fish pathogen in all fish species. The current study results presented preliminary information for better comprehension of the function of skin mucus as a key component in the different fish immune systems in aquaculture.
\end{abstract}

* Corresponding author. Tel.: +90 2522111904, Email: eozdemir@mu.edu.tr 


\section{Introduction}

The non-specific immune system is providing an essential barriers in the immune system of fish. They are a crucial factor in disease resistance of fish. Non-specific systems are divided into 3 parts: epithelial/mucosal barrier, humoral parameters and cellular components (Magnadottir, 2010). Intensive culture systems with associated stress and other husbandry risks greatly increases the threat of infection. Studies on skin mucus of fish could give information on health management in aquacultural systems. The immunological parameters of fish mucus provide knowledge about the health of fish. For that, a deeper knowledge of skin mucus is needed to search in order to prevent and control infectious diseases (Magnadottir, 2010; Esteban, 2012). The epithelial and mucosal barrier of skin and gills is a significant disease barrier in fish since they are constantly immersed in environment, possibly containing harmful agents. The aquatic environment is rich in pathogens (Dash et al., 2018). Hence, especially the skin is vital for aquatic organisms, and it is the first line of defence against pathogens (Magnadottir, 2010; Esteban, 2012).

The fish mucus layer also provides physical, biochemical, and chemical protection and contains various immune defense parameters such as lysozyme, myeloperoxidase, antimicrobial peptides, complement factors, and immunoglobulins (Magnadottir, 2005; Subramanian et al., 2008). A good variety of antimicrobial, enzymatic, and bactericidal activity studies on mucus in different fish species are reported in the literature (Magnadottir, 2010; Esteban, 2012; Dash et al., 2018). Antimicrobial skin mucus activities of various fish species include: Hypophthalmichthys nobilis, Ctenopharyngodon idella, and Cyprinus carpio (Kumari et al., 2019), O. niloticus, Clarias batrachus and Channa striata (Lirio et al., 2018), Catla catla, Cirrhinus mrigala and Anguilla anguilla (Pethkar and Lokhande, 2017), Labrus bergylta (Katra et al., 2016), O. mykiss (Hisar et al., 2014), Catla catla, Hypophthalmichthys molitrix, Labeo rohita and C. idella (Balasubramanian et al., 2012), Gadus morhua (Ruangsri, 2010), Mystus gulio and Arius maculatus (Anbuchezhian et al., 2011), Salvelinus alpinus, S. fontinalis, C. carpio, Morone saxatilis, Melanogrammus aeglefinus and Myxine glutinosa (Subramanian et al., 2008), C. punctatus and Cirrhinus mrigala (Kuppulakshmi et al., 2008) were documented by researches. Comparative analysis of immune responses was carried out on the mucus layer of different fish species (Subramanian et al., 2007; Nigam et al., 2012; Guardiola et al., 2014). These studies reported that some non-specific immune parameters varied in among fish species. The information available on the function of mucus is restricted to a few fish species.

This study was planned to provide information on lysozyme activity, myeloperoxidase activity, alkaline phosphatase activity, total protein amount, total immunoglobulin, and bactericidal activity in mucus of fish species; Oreochromis niloticus, Oncorhynchus mykiss, Acipenser baerii, and Dicentrarchus labrax. Especially sea bass and rainbow trout farming are important in the aquaculture industry also Nile tilapia and Siberian sturgeon are both potential species in Turkey. For the industry, it is necessary to gain more fish species. Such findings have the potential to contribute to the development of sustainable health management in these species.

Requirements.

\section{Materials and Methods}

\section{Ethics Statement}

Animals and methods used in this study were approved (MSKU 2020/9) by the Ethics Committee of Mugla Sıtkı Kocman University, Faculty of Fisheries.

\section{Fish Species}

Mucus samples of the four fish species (O. niloticus, O. mykiss, A. baerii and D. labrax) were obtained from Mugla-Oren Aquaculture Research Station, Turkey. The average total weight and length of fish species are displayed in Table 1. The fish contributed into four tanks as 15 fish/group and acclimated for two weeks before sampling. Artesian water was used as a water source. The water's specific qualities were measured using a multiprobe 
(YSI 556MPS) as such: temperature $18{ }^{\circ} \mathrm{C}$, pH 7.8-8.2 dissolved oxygen 5.5-6.5 mg/L and salinity $\% 2-3$. Fish were fed with $2 \%$ body weight of a commercial diet during trial.

Table 1 Average total weight and length of four fish species ( $\mathrm{n}: 15$ samples/fish species).

\begin{tabular}{lll}
\hline Fish & Average weight $(\mathrm{g})$ & Average length $(\mathrm{cm})$ \\
\hline O. mykiss (Rainbow trout) & $139.25 \pm 18.42$ & $16.98 \pm 1.83$ \\
O. niloticus (Nile tilapia) & $236.73 \pm 21.21$ & $20.54 \pm 1.00$ \\
D. labrax (Sea bass) & $201.89 \pm 18.03$ & $25.72 \pm 1.09$ \\
A. baerii (Siberian sturgeon) & $1414 \pm 3279.041$ & $94.90 \pm 6.20$ \\
\hline
\end{tabular}

\section{Mucus Sample Collection}

The mucus samples (15 fish/group) were obtained from four fish species at same day. The mucus of $O$. niloticus, $O$. mykiss, $A$. baerii and $D$. labrax was collected by a modified method of Subramanian et al. (2008). The fish were starved 24 hours before sampling. They were anesthetized with phenoxyethanol $(0.5 \mathrm{~mL} / \mathrm{L})$, and mucus samples were collected from dorsal part of the fish using a cell scraper. The samples were collected into Eppendorf centrifuge tubes and kept on ice until centrifuged at $1500 \mathrm{x} \mathrm{g}$ for $10 \mathrm{~min}$ at $4{ }^{\circ} \mathrm{C}$, and the supernatant obtained was aliquoted into $2 \mathrm{~mL}$ tubes. The collected fish mucus was stored at $-80^{\circ} \mathrm{C}$ until used.

\section{Lysozyme activity}

The lysozyme activity in skin mucus was measured according to the turbidimetric assay described by Parry et al., (1965). Briefly, $25 \mu \mathrm{L}$ of skin mucus was added to $175 \mu \mathrm{L}$ suspensions Micrococcus lysodeikticus (Sigma-Aldrich, lot no. \# 4698) in flat-bottomed 96well plates in triplicate. Microplate reader (Thermo Multiskan Go) utilization showed a reaction in absorbance $490 \mathrm{~nm}$ after 0.5 and $4.5 \mathrm{~min}$ at $22{ }^{\circ} \mathrm{C}$. The lysozyme activity, a unit of enzyme was defined as that quantity of enzyme that cause the decrease in absorbance of $0.001 \mathrm{~min}^{-1}$. The rate of reduction in absorbance of samples was converted to lysozyme concentration ( $\mu \mathrm{g} \mathrm{mL}^{-1}$ ) using a standard (HEWL Sigma, lot no. \# L6876) curve.

\section{Myeloperoxidase activity}

The myeloperoxidase activity was determined according to Quade and Roth (1997). $15 \mu \mathrm{L}$ of skin mucus were diluted with $135 \mu \mathrm{L}$ of Hank's balanced salt solution (without $\mathrm{Ca}^{+2}$, $\mathrm{Mg}^{+2}$ ) in flat-bottomed 96-well plates. As substrates, $50 \mu \mathrm{L}$ of $20 \mathrm{mM}$ TMB $(3,30,5,50$-tetra methyl benzidine, Sigma, lot no \# T3405) and $5 \mathrm{mM} \mathrm{H}_{2} \mathrm{O}_{2}$ were added. The color-change reaction was stopped after 2 min by adding $50 \mu \mathrm{L}$ of $4 \mathrm{M}$ sulphuric acid, and the optical density was read at $450 \mathrm{~nm}$ by a multiscan microplate reader (Thermo Multiskan Go).

\section{Total protein concentration}

Protein concentration in each mucus sample was determined according to the Bradford method (Bradford, 1976). The reaction was carried out in a 96 well plate, and the optical density was read at $595 \mathrm{~nm}$ in a plate reader (Thermo Multiskan Go). The units of total protein concentration present in skin mucus were obtained from a standard curve made with Bovine Serum Albumin (BSA Sigma, lot no \# B6916), and the results expressed as $\mathrm{mg} / \mathrm{mL}$.

\section{Total immunoglobulin amount}

Colorimetric assay, as explained by Siwicki and Anderson, (1993) was detected to calculate total immunoglobulin amount. Briefly, $100 \mu \mathrm{L}$ of each skin mucus sample was combined with equal volume polyethylene glycol solution and brought down immunoglobulin molecules. Following centrifuge at $1000 \times \mathrm{g}$ for $10 \mathrm{~min}$, the protein content of supernatant was measured. The following formula was utilized for the calculation of total immunoglobulin amount:

Total immunoglobulin level $\left(\mathrm{mg} \mathrm{mL}^{-1}\right)=$ Total protein in mucus/Total protein in supernatant 
Alkaline phosphatase activity

For the calculation of alkaline phosphatase activity, an equal volume of skin mucus samples with $4 \mathrm{mM}$ p-nitrophenyl liquid phosphate was incubated in $100 \mathrm{mM}$ ammonium bicarbonate buffer containing $1 \mathrm{mM} \mathrm{MgCl}_{2}\left(\mathrm{pH} 7.8,30^{\circ} \mathrm{C}\right.$ ) as explained by Ross et al. (2000). The samples were (Thermo Multiskan Go) measured the OD at $405 \mathrm{~nm}$. One unit of activity was defined as the amount of enzyme required to release $1 \mathrm{mmol}$ of $\mathrm{p}$ -

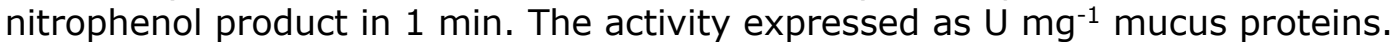

\section{Bactericidal activity}

The skin mucus bactericidal activity was determined by following Kajita et al. (1990) with some modifications. Aeromonas hydrophila (SY-AH2, Accession numbers: MG844996) was previously isolated from diseased fish and obtained from Dr. Sevdan YILMAZ (Çanakkale Onsekiz Mart University). A. hydrophila was grown in agar plates at $25^{\circ} \mathrm{C}$ in media. Then freshly prepared $A$. hydrophila culture was harvested by centrifugation, and the pellet was washed and suspended in PBS. The bacterial density was adjusted to 0.5 at optical density $546 \mathrm{~nm}$ wavelength (Rao et al., 2006). $100 \mu \mathrm{L}$ mucus sample and $100 \mu \mathrm{L}$ bacterial suspension were combined into a microplate well and slowly suspended before incubating at $25^{\circ} \mathrm{C}$ for 1 hour. Then the mixture was diluted with PBS at a ratio of $1: 10$ to determine the number of bacteria in each well/microplate. The skin mucus-bacterial suspension was plated as $100 \mu \mathrm{L}$ onto the tryptic soy agar plates at $25^{\circ} \mathrm{C}$ for $24 \mathrm{~h}$. As a result of incubation, the number of viable bacterial colonies counted. Control was also prepared by replacing mucus with sterile PBS instead of bacteria.

\section{Statistical Analysis}

The data are expressed as mean \pm standard error (SE). One-way analysis of variance was used for the statistical analysis of the data (ANOVA). In order to determine differences between groups. Duncan's pairwise multiple comparison test were followed. Different letters in the figures represent the significant difference at $P<0.05$.

\section{Lysozyme Activity}

\section{Results}

The effect of different fish species on the lysozyme activity in mucus is depicted in Figure 1. Lysozyme activity was significantly high $(P<0.05)$ in the skin mucus of $D$. labrax $(46.00 \pm 1.24 \mu \mathrm{g} / \mathrm{mL})$. The lysozyme activity was relatively low in $A$. baerii $(28.80 \pm 1.83$ $\mu \mathrm{g} / \mathrm{mL})$ and 0 . mykiss $(15.66 \pm 1.18 \mu \mathrm{g} / \mathrm{mL})$ and was lowest in O. niloticus $(12.20 \pm 0.79$ $\mu \mathrm{g} / \mathrm{mL})$. 


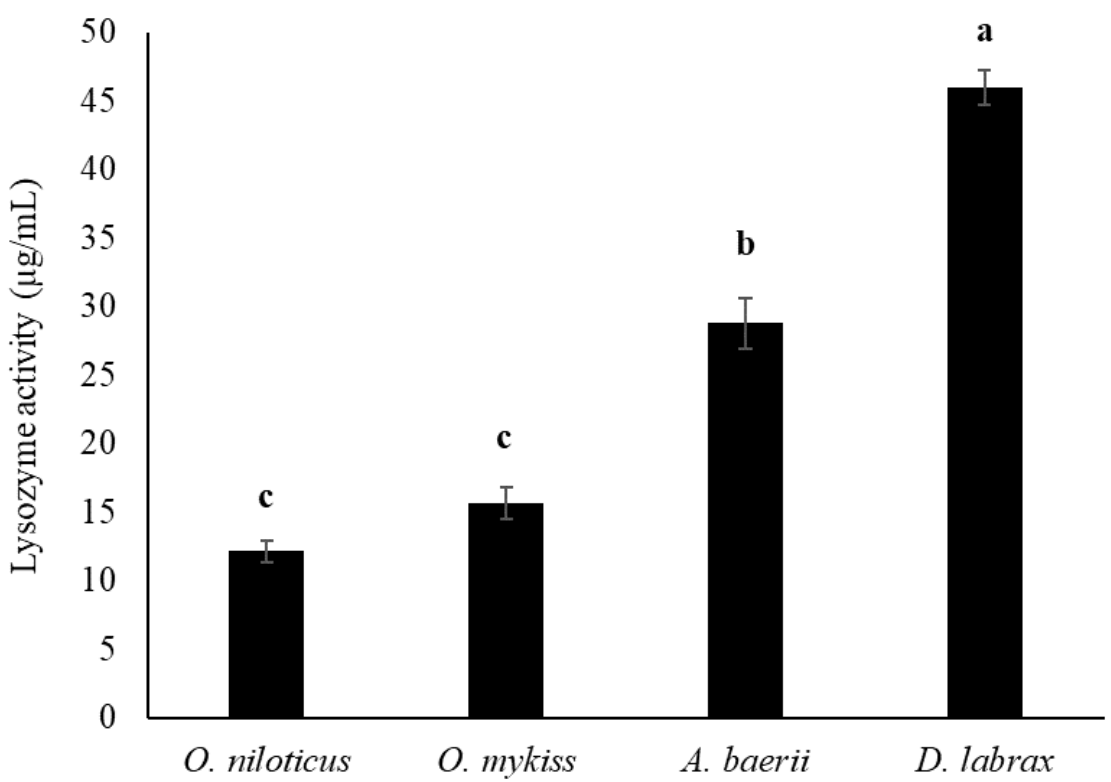

Figure 1 Lysozyme activity in skin mucus of four fish species: O. niloticus, O. mykiss, $A$. baerii, D. labrax. Values are expressed as mean \pm SE $(n=15 / g r o u p)$. Different letters denote significant differences between fish species $(P<0.05)$.

Myeloperoxidase Activity

The analysis of skin mucus showed (Figure 2) that the level of myeloperoxidase activity in $D$. labrax $(2.56 \pm 0.027$ unit/mL) was higher $(P<0.05)$ than in $A$. baerii $(1.47 \pm 0.032$ unit $/ \mathrm{mL})$. The activity of the enzyme was low $(0.83 \pm 0.025$ unit $/ \mathrm{mL})$ in 0 . niloticus and (0.55 \pm 0.021 unit $/ \mathrm{mL})$ O. mykiss.

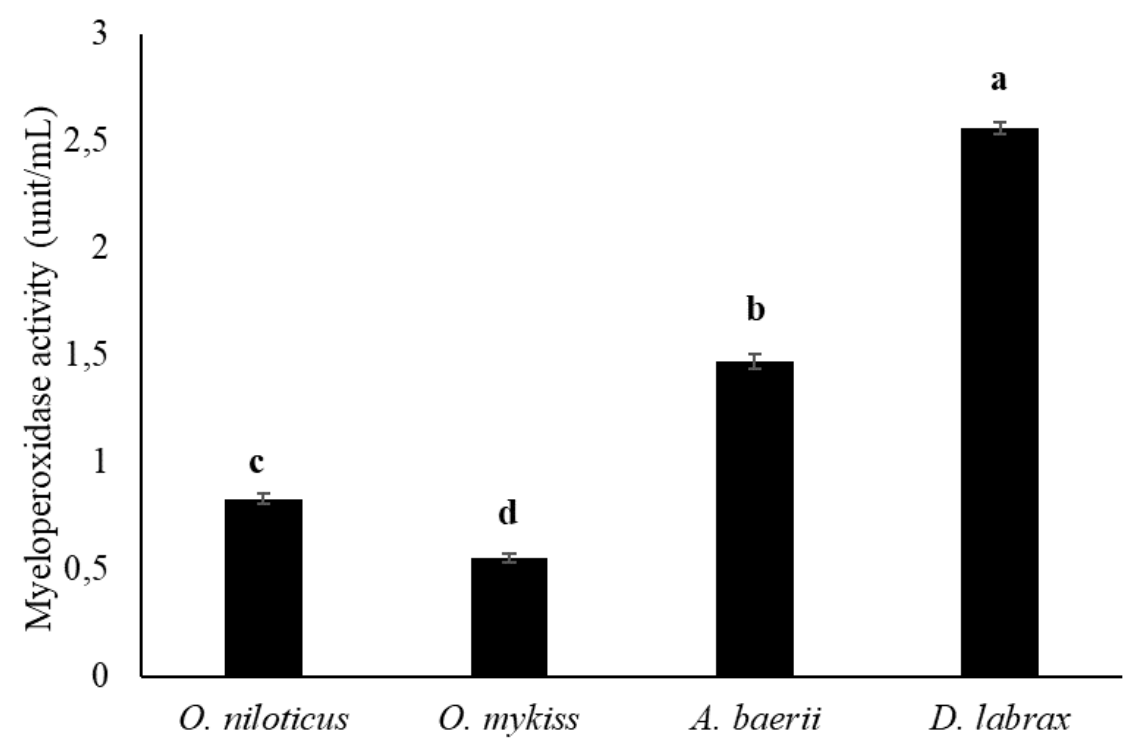

Figure 2 Myeloperoxidase activity in the skin mucus of four fish species. Values are expressed as mean \pm SE ( $n=15$ /group). Different letters denote significant differences between fish species $(P<0.05)$.

Alkaline Phosphatase Activity

The mucus alkaline phosphatase activity (Figure 3 ) showed that Nile tilapia mucus had the highest alkaline phosphatase activity ( $2.11 \pm 0.08 \mathrm{unit} / \mathrm{mg}$ protein). Rainbow trout 
mucus had the second highest $(P<0.05)$ alkaline phosphatase activity $(1.48 \pm 0.07$ unit/mg protein) followed by Siberian sturgeon (1.00 0.01 unit/mg protein) and sea bass (0.79 \pm 0.02 unit/mg protein).

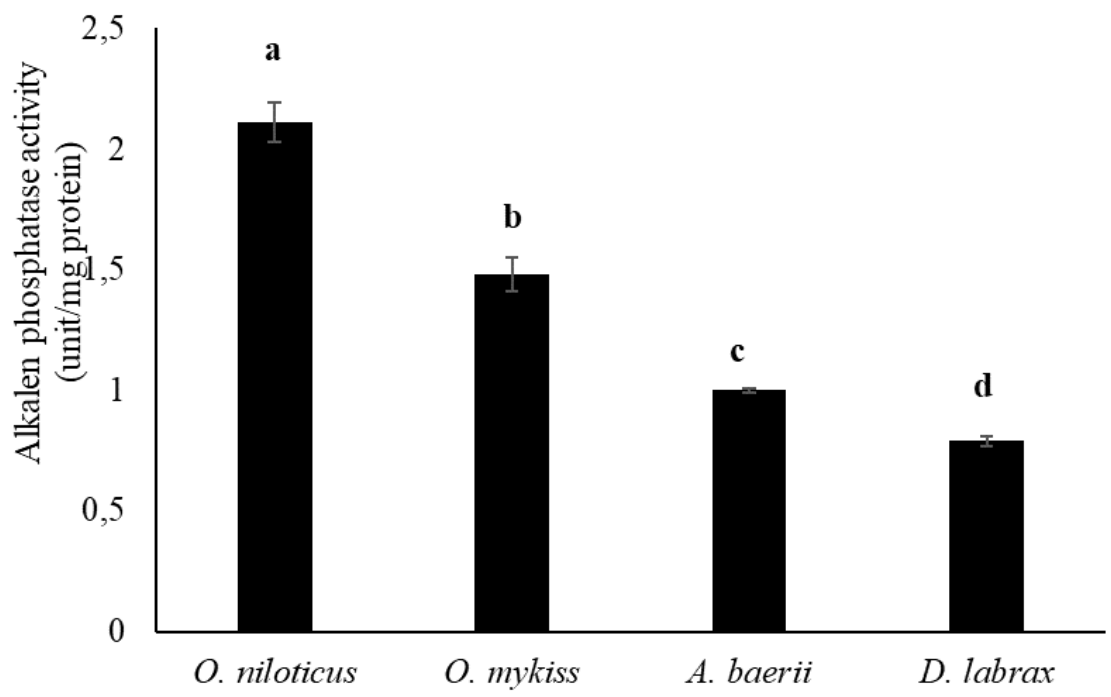

Figure 3 Alkaline phosphatase activity in skin mucus of the four selected fish species. Values are expressed as mean \pm SE ( $n=15 /$ group). Different letters denote significant differences between fish species $(P<0.05)$.

\section{Total Protein}

The total protein amount was very similar in all fish species (Figure 4). However, total protein in the skin mucus of $D$. labrax $(12.60 \pm 0.24 \mathrm{mg} / \mathrm{mL})$ and $A$. baerii $(12.44 \pm 0.22$ $\mathrm{mg} / \mathrm{mL})$ were higher $(\mathrm{P}<0.05)$ than that of $O$. niloticus $(11.59 \pm 0.38 \mathrm{mg} / \mathrm{mL})$ and $O$. mykiss $(11.45 \pm 0.30 \mathrm{mg} / \mathrm{mL})$.

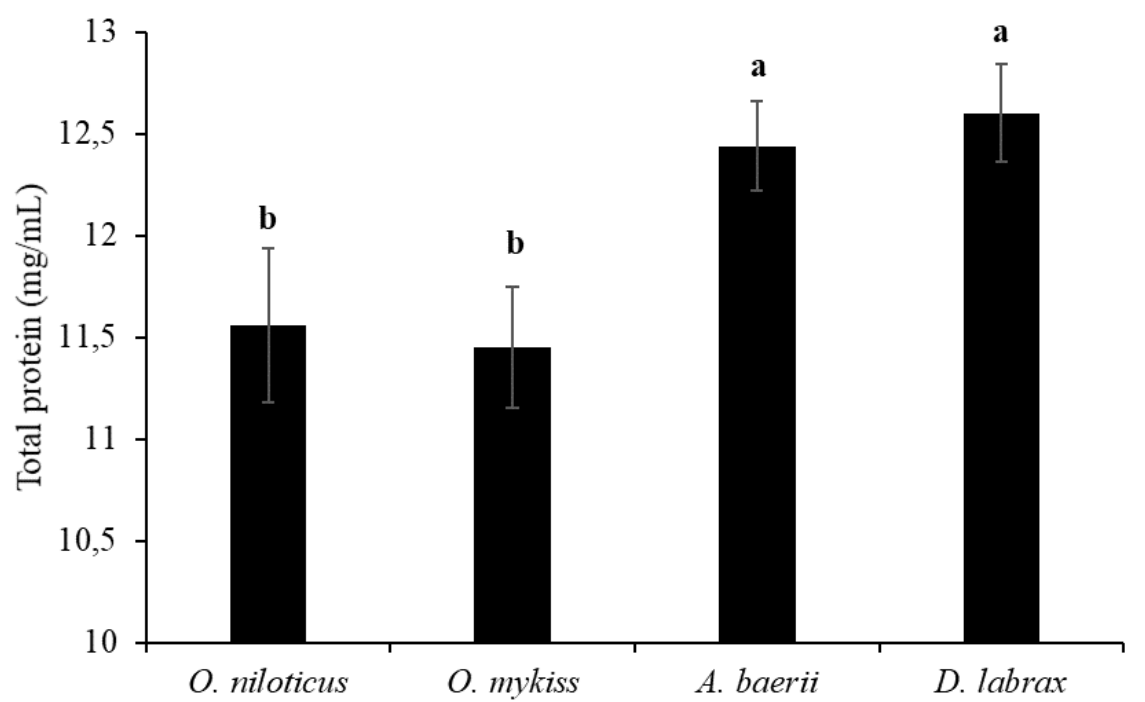

Figure 4 The total protein amount in skin mucus of fish species. Values are expressed as mean \pm SE ( $n=15 /$ group). Different letters denote significant differences between fish species $(P<0.05)$.

\section{Total Immunoglobulin}

The total immunoglobulin levels in the skin mucus of all fish species showed significant differences $(P<0.05)$ and are showed in Figure 5. The total immunoglobulin level was significantly high $(P<0.05)$ in the skin mucus of $D$. labrax $(4.95 \pm 0.26 \mathrm{mg} / \mathrm{mL})$ and $A$. baerii $(4.11 \pm 0.17 \mathrm{mg} / \mathrm{mL})$. In contrast, significantly trim levels of total immunoglobulin 
were determined in the skin mucus of 0 . mykiss $(3.33 \pm 0.18 \mathrm{mg} / \mathrm{mL})$ and $O$. niloticus $(2.57 \pm 0.14 \mathrm{mg} / \mathrm{mL})$.

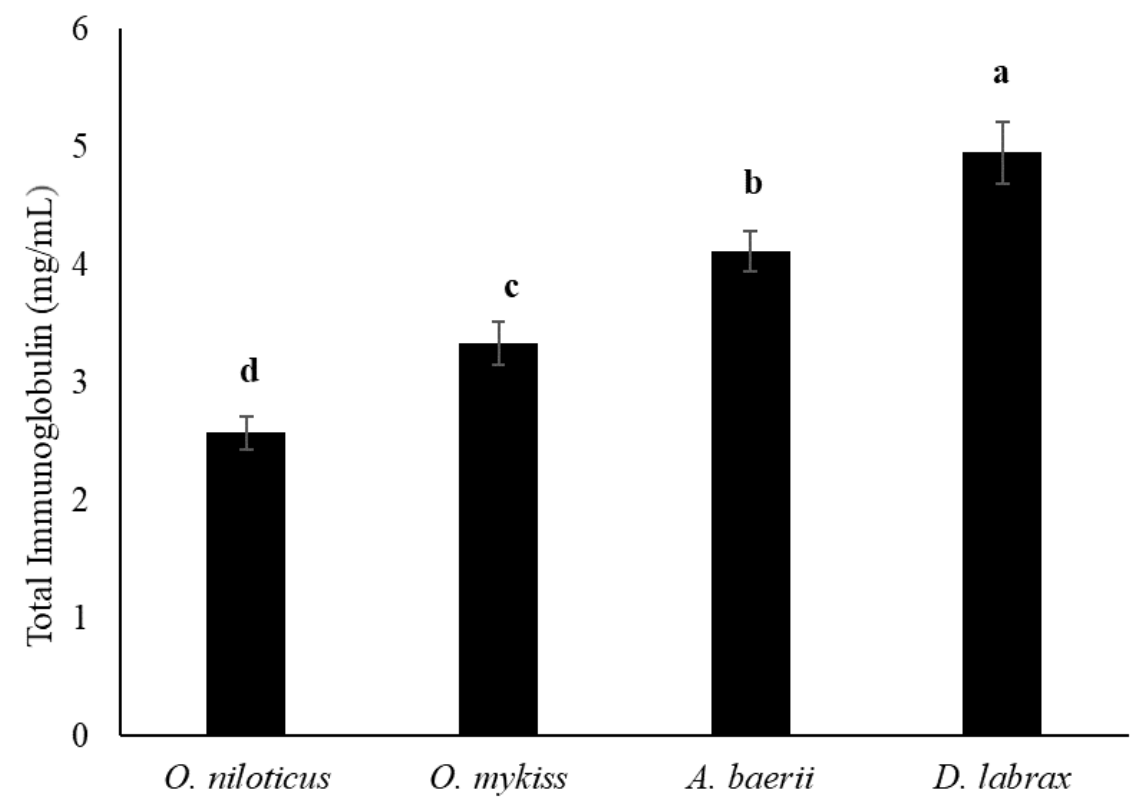

Figure 5 The total immunoglobulin level in the skin mucus of fish species. Values are expressed as mean \pm SE ( $n=15 /$ group). Different letters denote significant differences between fish species $(P<0.05)$.

\section{Bactericidal Activity}

The bactericidal activity of the skin mucus from 0 . niloticus, O. mykiss, A. baerii and $D$. labrax was determined against $A$. hydrophila (Figure 6). Among selected fish species, the skin mucus of sea bass showed the highest $(P<0.05)$ bactericidal activity $(35.86 \pm 1.34$ $\mathrm{CFU} / \mu \mathrm{L})$ followed by Siberian sturgeon $(40.60 \pm 0.79 \mathrm{CFU} / \mu \mathrm{L})$, rainbow trout $(41.40 \pm 0.87$ $\mathrm{CFU} / \mu \mathrm{L})$. Nile tilapia skin mucus had the lowest level $(50.93 \pm 1.24 \mathrm{CFU} / \mu \mathrm{L})$ of bactericidal activity against $A$. hydrophila bacterial fish pathogen.

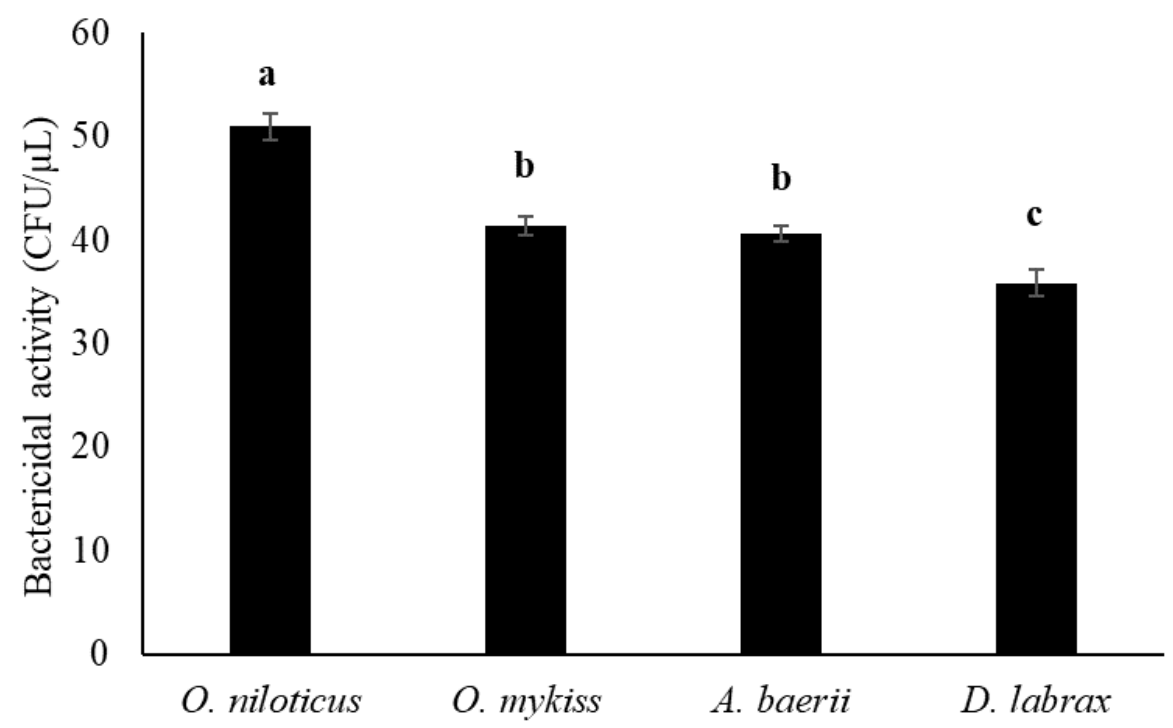

Figure 6 The bactericidal activity in the skin mucus of fish species. Values are expressed as mean $\pm S E(n=15 /$ group). Different letters denote significant differences between fish species $(P<0.05)$.

\section{Discussion}


Fish epidermal mucus layer and its components provide the first line of defense against pathogens. The different components of the fish skin mucus: water, glycoproteins, mucin, complement, protease, C-reactive proteins, lectins, cathepsins, defensins, hemolysins, immunoglobulin M (IgM), agglutinin, proteolytic enzymes, antimicrobial peptides, acid and alkaline phosphatases, superoxide dismutase, and lysozyme act as inhibitory agents against various diseases caused by infections (Subramanian et al., 2007; Esteban 2012; Guardiola et al., 2014). In our selected fish species skin mucus were found lysozyme, myeloperoxidase and bactericidal activities. Also, we measured total protein, total immunoglobulin, and alkaline concentrations. The parameters under inspection in this study showed variety based on the fish species.

Lysozyme activity is an essential component in the first line of barriers in the innate immune system. Lysozyme has bacteriolytic activity in the fish mucus layer and mediates protection against bacterial infections (Magnadottir, 2006). Lysozyme activity in the mucus varied indicated variety among the fish species worked inspected and could reflect the differences in resistance levels of the fish resistance to bacterial pathogens (Subramarian et al., 2007; Nigam et al., 2012; Guardiola et al., 2014; Ghafoori et al., 2014a). Analysis of this study, results determined for lysozyme activity data in O. niloticus, O. mykiss, A. baerii and $D$. labrax indicated significant differences between sampled fish species. The lysozyme activity present in the skin mucus of sea bass showed high values. Also, the lysozyme activity was significantly higher in the skin mucus of the marine fishes than that of the freshwater species in this study. It has been documented that significantly higher lysozyme activity in the skin mucus of marine fish species (Subramarian et al., 2007) than that of the species reared in freshwater species. The opposite was also documented (Fast et al., 2002). The level and activity of lysozyme in the skin mucus depends on environmental conditions as well as the fish species (Fast et al., 2002; Jung et al., 2012; Nigam et al., 2012).

Myeloperoxidase activity is another important enzyme that plays a role in the killing of microorganisms in the innate system (Johnston, 1978). Some works have shown significant variability of the myeloperoxidase activity in various fish species (Subramarian et al., 2007; Nigam et al., 2012, Guardiola et al., 2014; Guardiola et al., 2014a). In this study the myeloperoxidase activity in sea bass skin mucus was significantly higher than in other fish species. Similarly, myeloperoxidase activity increased significantly in seabream skin mucus (Guardiola et al., 2014a). Also, Guardiola et al. (2014) reported increases in myeloperoxidase activity in several marine teleost fish (Sparus aurata, Dicentrarchus labrax, Umbrina cirrosa, Dentex dentex, and Epinephelus marginatus) skin mucus.

Alkaline phosphatase is an essential lysosomal enzyme associated with the non-specific immune system and has also been identified in the mucus of fish (Nigam et al., 2012). The present study demonstrated a significant difference in the specific activities' alkaline phosphatase in the skin mucus of $O$. niloticus and $O$. mykiss and low in $A$. baerii and $D$. labrax. Subramarian et al. (2007) documented a higher concentration of alkaline phosphatase in skin mucus fish species such as hagfish and koi carp compared to brook trout, haddock, Arctic char, and Atlantic cod. Guardiola et al. (2014) reported a similar result of enzyme in seabream, sea bass, shi drum, common dentex while the dusky grouper amounts alkaline phosphatase was high or low respectively. Alkaline phosphatase activity was detected with significant differences in the specific activities of these enzymes observed among fish species (Fast, 2002; Nigam et al., 2012). The present work detected no meaningful relationship between the alkaline phosphatase activity and other mucosal innate parameters. The role of the alkaline phosphatase activity has not been determined concerning innate mucosal immunity (Nigam et al., 2012). Nevertheless, alkaline phosphatase activity is considered to indicate physical or chemical stress, or immunostimulation, microbial and parasitic infections (Iger and Abraham, 1997; Subramanian et al., 2008a).

The proteins include the humoral factors of the non-specific immune system (Magnadottir, 2006). By examining previous studies, it was found that the mucus has different total protein amounts depending on the fish species and environmental values in which they lived. In the present study, the difference between the total protein level of 
four fish species was not as significant. According to the current study, protein concentration was the highest in $D$. labrax. The lowest protein value was observed in $O$. mykiss. The mucus total protein amount was measured in male and female Caspian kutum (Rutilus frisii kutum) under seasonal temperature, gonadal growth and reproductive migration. There was no significant difference in mucus total protein both for male and female specimens in some months. However, the total protein concentration in different stages of ovarian growth detected significant variations (Ghafoori et al., 2014). Accordingly, in their study, mucus the total protein concentration of the Caspian kutum was detected and exhibited that total protein was also affected by temperature and gonadal growth. Many previous reports (Stosik et al., 2001; Abbas et al., 2020) showed that some factors such as fish species, temperature, different ecological niches, methods of collection of mucus, different developmental stages might cause changes in the amount of total protein in fishes. The results of the current study are in agreement with these prior studies.

Regarding humoral immune activity, immunoglobulins are a crucial aspect of adaptive immunity. The immunoglobulin in the fish was found to be a tetrameric IgM molecule (Wilson et al., 1995). Teleost IgM has an essential function as an immune molecule (Ross et al., 1998). Its structure, physiological characteristics, soluble forms, and membranebound forms, teleost IgM is similar to mammalian IgM (Ellis, 1990). Immunoglobulin M (IgM), which can be explained as the primary antibody of fish, and the main constituent of the humoral immune system in the teleost, has the potential to determine and neutralize foreign antigens such as bacteria and viruses (Guzman-Villanueva et al., 2014). In the present study, total immunoglobulin was detected in all fish species. Especially the highest total immunoglobulin value was determined in sea bass, followed by Siberian sturgeon. The value was detected to be lower in rainbow trout and Nile tilapia. In support of our study, Guardiola et al. (2014a) determined the immunoglobin levels in a good variety of various marine fish. Previous studies have documented a considerable individual variation in mucus total immunoglobulin levels among fish. Regarding the specific components, previous data results exhibited the presence of total immunoglobulin in gilthead seabream (Guardiola et al., 2014) skin mucus as it occurs in olive flounder (Palaska et al., 2008), channel catfish (Zilberg et al. 1997), common carp (Rombout et al. 1993), rainbow trout (Cain et al., 2000) and Atlantic salmon (Hatten et al., 2001; Valdenegro-Vega et al., 2013).

As Ellis noted (2001) that serum bactericidal activity is a mechanism to kill and clear pathogenic organisms in fish. A. hydrophila was used as a model to examine the effectiveness of both supplements to kill the bacterial infection. The lowest number of bacterial colonies indicated the efficiency of immune cells in mucus to kill the pathogen. However, the results of the current study revealed significantly higher mucus bactericidal activity in different fish species. Especially strong bactericidal activity was detected in sea bass. Some works shown that the skin mucus of different fish species has a strong antimicrobial, antibacterial and antifungal activity against bacteria and fungi fish pathogen (Hellio et al., 2002; Subramanian et al., 2008; Katra et al., 2016; Pethkar and Lokhande, 2017; Soltanian and Gholamhosseini, 2019; Kumari et al., 2019). Our study showed similar results to other marine teleost fish (against fish pathogenic Vibrio harveyi, $V$. angillarum, Photobacterium damselae) (Guardiola et al., 2014a), seabream (against fish pathogenic $V$. harveyi, V. angillarum, $P$. damselae). This study data also confirms the above finding and evidences that the skin mucus from the four fish species detected bactericidal activity against $A$. hydrophila fish bacterial pathogen.

As a result, sea bass and rainbow trout farming are valuable species in the aquaculture industry in Turkey. Nile tilapia and Siberian sturgeon are both potential species. For the industry, it is necessary to gain more. It has been established that some immune parameters play a role of fish-skin mucus in protection against pathogenic bacteria in fish species inhabiting different ecological niches with different microbial loads. Increased knowledge of the mucosal innate immune factors could be advantageous for aquaculture. Our result determines that marine and freshwater fish species have one or more immune activities high, but never all the activities are high or low. In the light of this information, previous studies have shown that the presence and activity of immune factors in the skin 
mucus depends on the environmental factors and the different fish species. Nevertheless, there is a need for further studies to deepen the knowledge of the fish mucus parameters and to determine their precise role in mucosal immunity.

\section{Acknowledgements}

I thank Süleyman BABA for his moral support during the work. I thank Mustafa HAC ISA for his help in the field work. Also, I thank Dr. Burcu BABA, Dr. Sevdan YILMAZ for their help in article writing.

\section{References}

Abbas, F., Hafeezur-Rehman, M., Asraf, M., Iqbal, K.J., Andleeb, S., Khan, B.A., 2020. Mucus properties of Chinese carp and Indian carp: Physical barrier to pathogens. Iranian Journal of Fisheries Sciences, 19(3): 1224-1236. https://doi.org/10.22092/ijfs.2019.119394.0.

Anbuchezhian, R., Gobinath, C., Ravichandran, S., 2011. Antimicrobial peptide from the epidermal mucus of some estuarine cat fishes. World Applied Sciences Journal, 12(3): 256-260.

Balasubramanian, S., Baby Rani, P., Arul Prakash, A., Prakash, M., Senthilraja, P., Gunasekaran, G., 2012. Antimicrobial properties of skin mucus from four freshwater cultivable fishes (Catla catla, Hypophthalmichthys molitrix, Labeo rohita and Ctenopharyngodon idella). African Journal of. Microbiology Research, 6(24): 5110-5120. https://doi.org/10.5897/AJMR11.532.

Bradford, M.M., 1976. A rapid method for the quantification of microgram quantities of protein utilizing the principle of protein dye binding. Analytical Biochemistry, 72: 248-254. https://doi.org/10.1016/0003-2697(76)90527-3.

Cain, K.D., Jones, D.R., Raison, R.L., 2000. Characterisation of mucosal and systemic immune responses in rainbow trout (Oncorhynchus mykiss) using surface plasmon resonance. Fish and Shellfish Immunology, 10: 651-666. https://doi.org/10.1006/fsim.2000.0280.

Dash, S., Das, S.K., Samal, J., Thatoi, H.N., 2018. Epidermal mucus, a major determinant in fish health: a review. Iranian Journal of Veterinary Research, 19(2): 72-81. https://doi.org/10.22099/ijvr.2018.4849.

Ellis, A.E., 2001. Innate host defence mechanism of fish against viruses and bacteria. Developmental and Comparative Immunology, 25: 827-839. https://doi.org/10.1016/s0145-305x(01)00038-6.

Ellis, A.E., 1990. Lysozyme assays. Pages 101-103 in Stolen, J.S., Fletcher, T.C., Anderson, D.P., Roberson, B.S., Van Muiswinkel,W.B., editor. Techniques in Fish Immunology. 1st ed. SOS Publications, New Jersey.

Esteban, M.A., 2012. An overview of the immunological defenses in fish skin. International Scholarly Research Notices Immunology, 853470: 1-29. https://doi.org/10.5402/2012/853470.

Fast, M.D., Sims, D.E., Burka, J.F., Mustafa, A., Ross, N.W., 2002. Skin morphology and humoral non-specific defence parameters of mucus and plasma in rainbow trout, coho and Atlantic salmon. Comparative Biochemistry \& Physiology, 132: 645-657. https://doi.org/10.1016/S1095-6433(02)00109-5.

Ghafoori, Z., Heidari, B., Farzadfar, F., Aghamaali, M., 2014. Variations of serum and mucus lysozyme activity and total protein content in the male and female Caspian kutum (Rutilus frisii kutum, Kamensky 1901) during reproductive period. Fish and Shellfish Immunology, 37: 139-146. https://doi.org/10.1016/j.fsi.2014.01.016.

Guardiola, F.A., Cuesta, A., Abellan, E., Meseguer, J., Esteban, M.A., 2014. Comparative analysis of the humoral immunity of skin mucus from several marine teleost fish. Fish and Shellfish Immunology, 40: 24-31. https://doi.org/10.1016/j.fsi.2014.06.018.

Guardiola, F.A., Cuesta, A., Arizcun, M., Meseguer, J., Esteban, M.A., 2014a. Comparative skin mucus and serum humoral defence mechanisms in the teleost gilthead 
seabream (Sparus aurata). Fish and Shellfish Immunology, 36: 545-551. https://doi.org/10.1016/j.fsi.2014.01.001.

Guzman-Villanueva, L.T., Tovar-Ramirez, D., Gisbert, E., Cordero, H., Guardiola, F.A., Cuesta, A., Meseguer, J., Ascencio-Valle, F., Esteban, M.A., 2014. Dietary administration of beta-1,3/1,6-glucan and probiotic strain Shewanella putrefaciens, single or combined, on gilthead seabream growth, immune responses and gene expression. Fish and Shellfish Immunology, 39(1): 34-41. https://doi.org/10.1016/j.fsi.2014.04.024.

Hatten, F., Fredriksen, A., Hordvik, I., Endresen, C., 2001. Presence of IgM in cutaneous mucus, but not in gut mucus of Atlantic salmon, Salmo salar. Serum IgM is rapidly degraded when added to gut mucus. Fish Shellfish Immunol. 11(3): 257-268. https://doi.org/10.1006/fsim.2000.0313.

Hellio, C., Pons, A.M., Beaupoil, C., Bourgougnon, N., Le Gal, Y., 2002. Antibacterial, antifungal and cytotoxic activities of extracts from fish epidermis and epidermal mucus. International Journal of Antimicrobial Agents, 20: 214-219. https://doi.org/10.1016/s0924-8579(02)00172-3.

Hisar, O., Hisa, S.A., Uyanik, M.H., Sahin, T., Caki, F., Yilmaz, S., 2014. In vitro antimicrobial and antifungal activities of aqueous skin mucus from rainbow trout (Oncorhynchus mykiss) on human pathogens. Marine Science and Technology Bulletin, 3(1): 19-22.

Iger, Y., Abraham, M., 1990. The process of skin healing in experimentally wounded carp. Journal of Fish Biology, 36: 421-437. https://doi.org/10.1111/j.10958649.1990.tb05622.x.

Johnston, R.B., 1978. Oxygen metabolism and the microbicidal activity of macrophages. Federation Proceedings, 37: 2759-2764.

Jung, T.S., Del Castillo, C.S., Javaregowda, P.K., Dalvi, R.S., Nho, S.W., Bin Park, S., Bin Jang, H., Cha, I.S., Sung, H.W., Hikima, J.I., Aoki, T., 2012. Seasonal variation and comparative analysis of non-specific humoral immune substances in the skin mucus of olive flounder (Paralichthys olivaceus). Developmental and Comparative Immunology, 38: 295-301. https://doi.org/10.1016/j.dci.2012.06.005.

Kajita, Y., Sakai, M., Atsuda, S., Kobayashi, M., 1990. The immunonodulatory effect of levamisole on rainbow trout Oncorhynchus mykiss. Fish Pathology, 25: 93-98.

Katra, N., Hisar, O., Yılmaz, S., Turgay, E., Sarvan, C., Karataş, S., 2016. In vitro antimicrobial activities of extracts from ballan wrasse (Labrus bergy/ta) skin mucus. Marine Science and Technology Bulletin, 5(1): 13-15.

Kumari, S., Tyor, A.K., Bhatnagar, A., 2019. Evaluation of the antibacterial activity of skin mucus of three carp species. International Aquatic Research, 11: 225-239. https://doi.org/10.1007/s40071-019-0231-z.

Kuppulakshmi, C., Prakash, M., Gunasekaran, G., Manimegalai, G., Sarojini, S., 2008. Antibacterial properties of fish mucus from Channa punctatus and Cirrhinus mrigala. Eur Rev Med Pharmacol Sci. 12(3): 149-153.

Lirio, G.A.C., De Leon, J.A.A., Villafuerte, A.G., 2019. Antimicrobial activity of epidermal mucus from top aquaculture fish species against medically-important pathogens. Walailak Journal of Science and Technology, 16(5): 329-340. https://doi.org/10.48048/wjst.2019.6287.

Magnadottir, B., Lange, S., Gudmundsdottir, S., Bøgwald, J., Dalmo, R.A., 2005. Ontogeny of humoral immune parameters in fish. Fish and Shellfish Immunology, 19: 429439. https://doi.org/10.1016/j.fsi.2005.03.010.

Magnadottir, B., 2010. Immunological control of fish diseases. Marine Biotechnology, 12: 361-379.

Magnadottir, B., 2006. Innate immunity of fish. Fish and Shellfish Immunology, 20, 137151. https://doi.org/10.1016/j.fsi.2004.09.006.

Nigam, A.K., Kumari, U., Mittal, S., Mittal, A.K., 2012. Comparative analysis of innate immune parameters of the skin mucous secretions from certain freshwater teleosts, inhabiting different ecological niches. Fish Physiology and Biochemistry, 38: 1245-1256. https://doi.org/10.1007/s10695-012-9613-5. 
Palaksha, K.J., Shin, G.W., Kim, Y.R., Jung, T.S., 2008. Evaluation of non-specific immune components from the skin mucus of olive flounder (Paralichthys olivaceus). Fish and Shellfish Immunology, 24: 479-488. https://doi.org/10.1016/j.fsi.2008.01.005.

Parry, R.M., Chandan, R.C., Shahani, K.M., 1965. A rapid and sensitive assay of muramidase. Proceedings of the Society for Experimental Biology and Medicine, 119: 384386. https://doi.org/10.3181/00379727-119-30188.

Pethkar, M.R., Lokhande, M.V., 2017. Antifungal activity of skin mucus of three cultivable fish species (Catla catla, Cirrhinus mrigala and Anguilla anguilla). International Journal of Zoology Studies, 2(6): 2455-7269.

Quade, J.M., Roth, J.A., 1997. A rapid, direct assay tomeasure degranulation of bovine neutrophil primary granules. Veterinary Immunology and Immunopathology, 58: 239-248. https://doi.org/10.1016/s0165-2427(97)00048-2.

Rao, V., Chakrabarti, R., 2005. Stimulation of immunity in Indian major carp Catla catla with herbal feed ingredients. Fish and Shellfish Immunology, 18(4): 327-334. https://doi.org/10.1016/j.fsi.2004.08.005.

Rombout, J.H., Taverne, N., Van De Kamp, M., Taverne-Thiele, A.J., 1993. Differences in mucus and serum immunoglobulin of carp (Cyprinus carpio L.). Developmental and Comparative Immunology, 17: 309-317. https://doi.org/10.1016/0145-305x(93)90003-9.

Ross, N.W., Firth, K.J., Wang, A., Burka, J.F., Johnson, S.C., 2000. Changes in hydrolytic enzyme activities of naïve Atlantic salmon Salmo salar skin mucus due to infection with the salmon louse Lepeophtheirus salmonis and cortisol implantation. Diseases of Aquatic Organisms, 41: 43-51. https://doi.org/10.3354/dao041043.

Ross, D.A., Wilson, M.R., Miller, N.W., Clem, L.W., Warr, G.W., 1998. Evolutionary variation of immunoglobulin $\mu$-heavy chain RNA processing pathways, origins, effects, and implications. Immunological Reviews, 166(1): 143-151. https://doi.org/10.1111/j.1600065x.1998.tb01259.x.

Ruangsri, J., Fernandes, J.M.O., Brinchmann, M., Kiron, V., 2010. Antimicrobial activity in the tissues of Atlantic cod (Gadus morhua L.). Fish and Shellfish Immunology, 28: 879-886. https://doi.org/10.1016/j.fsi.2010.02.006.

Siwicki, A., Anderson, D., 1993. Immunostimulation in fish: measuring the effects of stimulants by serological and immunological methods. US, Fish Wildl Service-IFI 1, pp.117.

Soltanian, S., Gholamhosseini, A., 2019. The effects of starvation on some epidermal mucus immune parameters in rainbow trout, Oncorhynchus mykiss. International Journal of Aquatic Biology, 7(5): 291-300. https://doi.org/10.22034/ijab.v7i5.634.

Stosik, M., Deptula, W., Travnicek, M., 2001. Resistance in carps (C. carpio L.) affected by a natural bacterial infection. Veterinary Medicine Czech, 46: 6-11. https://doi.org/10.17221/7844-VETMED.

Subramanian, S., MacKinnon, S., Ross, N.A., 2007. Comparative study on innate immune parameters in the epidermal mucus of various fish species. Comparative Biochemistry and Physiology PartB: Biochemistry \& Molecular Biology, 148: 256-263. https://doi.org/10.1016/j.cbpb.2007.06.003.

Subramanian, S., Ross, N.W., Mackinnon, S.L., 2008. Comparison of antimicrobial activity in the epidermal mucus extracts of fish. Comparative Biochemistry and Physiology Part B: Biochemistry \& Molecular Biology, 150: 85-92. https://doi.org/10.1016/j.cbpb.2008.01.011

Subramanian, S., Ross, N.W., MacKinnon, S.L., 2008a. Comparison of the biochemical composition of normal epidermal mucus and extruded slime of hagfish (Myxine glutinosa L.). Fish and Shellfish Immunology, 25: 625-632. https://doi.org/10.1016/j.fsi.2008.08.012.

Valdenegro-Vega, V.A., Crosbie, P.., Vincent, B., Cain, K.D., Nowak, B.F., 2013. Effect of immunization route on mucosal and systemic immune response in Atlantic salmon (Salmo salar). Veterinary Immunology and Immunopathology, 151: 113-123. https://doi.org/10.1016/j.vetimm.2012. 
Wilson, M.R., van Ravenstein, E., Miller, N.W., Clem, L.W., Middleton, D.L., Warr, G.W., 1995. cDNA sequences and organization of IgM heavy chain genes in two holostean fish. Developmental \& Comparative Immunology, 19: 153-164. https://doi.org/10.1016/0145-305x(94)00063-I.

Zilberg, D., Klesius, P.H., 1997. Quantification of immunoglobulin in the serum and mucus of channel catfish at different ages and following infection with Edwardsiella ictaluri. Veterinary Immunology and Immunopathology, 8: 171-180. https://doi.org/10.1016/s0165-2427(97)00033-0. 